\title{
PEMIKIRAN AHMAD TAFSIR TENTANG GURU DALAM PENDIDIKAN ISLAMI DAN RELEVANSINYA DENGAN SISTEM PENDIDIKAN NASIONAL
}

\author{
JAJANG BADRUZAMAN
}

\begin{abstract}
Jajang Badruzaman Universitas Ibn Khaldun
\end{abstract}

Email badru0103@yahoo.co.id

\section{Abstract}

Teachers in Islam are the ones who are responsible for the development of the students by seeking all their potential, both affective potential, cognitive potential, and psychomotor potential. Teachers also mean responsible adults to provide help to the students in their physical and spiritual development in order to reach maturity level, and be able to stand alone in fulfilling their duties as servants of God.

The focus of the problem in this study is to examine Ahmad Tafsi's thinking about teachers in Islamic education and its relevance to the National Education System Law. The purpose of this research is to increase the knowledge of whether Ahmad Tafsir's thoughts on Teachers in Islamic education are relevant to the National Education System Law. The method used is descriptive qualitative by using approach of research of library research or library research. The research technique used is analysis study.

From the results of this study the researchers found that Ahmad Tafsir's thought about teachers in Islamic education is the task of teachers is to educate, the task of most teachers is to educate by way of teaching. Being a qualified teacher is certainly not just teaching but must meet the nature and requirements that reflect the teacher is professional, authoritative, appropriate to be obeyed and followed, responsible, and others.

Keywords: Teachers, Islamic education; Sisdiknas No 14 of 2005 on Teachers and Lecturers, Relevance of thought 


\section{A. Pendahuluan}

Islam sebagai agama sempurna memiliki perspektif sendiri dalam memandang pendidikan. Pendidikan dalam perspektif Islam memiliki perbedaan yang dominan jika dibandingkan dengan pendidikan dalam perspektif Barat. Salah satu keutamaan Islam adalah kesempurnaan ajaranya, Islam berasal dari Allah yang Maha Sempurna. Kesempurnaan Islam terletak pada keluasan cakupan ajarannya. Tidak ada satupun masalah di dunia ini yang tidak diselesaikan oleh ajaran Islam. Ajaran Islam sebagai solusi meliputi segala permasalahan manusia di dunia. Islam sebagai sebuah solusi juga meliputi berbagai aspek kehidupan manusia, baik ekonomi, politik, sosial, budaya maupun pendidikan.

Kesempurnaan ajaran dan konsep Islam telah diakui bukan hanya oleh orang Muslim, bahkan para pakar non muslimpun mengakuinya. Bernand Shaw, seorang filosof Inggris sebagaimana diungkapkan oleh Muhammad lqbal, pernah mengatakan bahwa agama yang dibawa Nabi Muhammad telah menjadi tolak ukur yang sempurna karena meliputi gairah yang mengagumkan dalam urusan dunia sekaligus urusan akhirat.
Guru (dalam Bahasa jawa) adalah seorang yang harus digugu dan harus ditiru oleh semua muridnya. Harus digugu artinya segala sesuatu yang disampaikan olehnya senantiasa dipercaya dan diyakini sebagai kebenaran oleh semua murid. Segala ilmu pengetahuan yang didatangkan dari seorang guru dijadikan sebuah kebenaran yang tidak perlu dibuktikan atau diteliti lai. Seorang guru juga harus ditiru, artinya seorang guru menjadi suri teladan bagi semua muridnya. Mulai dari cara berfikir, cara bicara, dan cara berperilakunya sehari-hari. Sebagai seseorang yang harus digugu dan ditiru, dengan sendirinya seorang guru memiliki peran yang luar biasa dominannya bagi murid.

Kedudukan guru sebagai pendidikan dan pembimbing tidak bisa dilepaskan dari guru sebagai pribadi. Kepribadian guru sangant mempengaruhi peranannya sebagai pendidik dan pembimbing. Dia mendidik dan membimbing para siswa tidak hanya dengan bahan yang ia sampaikan atau dengan metode-metode penyampaian yang digunakannya, tetapi dengan seluruh kepribadiannya. Mendidik dan membimbing tidak hanya terjadi dalam interaksi formal, tetati 


\section{Pemikiran Ahmad Tafsir tentang Guru:...(Jajang Badruzaman)}

juga interaksi informal, tidak hanya diajarkan tetapi juga ditularkan. Pribadi guru merupakan suatu kesatuan antara sifat-sifat pribadinya, dan peranannya sebagai pendidikan dan pembimbing.

Guru menempati peran kunci dalam mengelola kegiatan pembelajaran. Peran kunci ini dapat diemban apabila ia memiliki tingkat kemampuan professional yang tinggi. Kemampuan professional guru itu tidak diukur dari kemampuan intelektualnya saja melainkan juga dituntut untuk memiliki keunggulan dalam aspek moral, keimanan, ketaqwaan, disiplin, tanggung jawab, kedalaman ilmu dan keluasan wawasan kependidikanya dalam mengelola kegiatan pembelajaran. Keluasan wawasan ini dicirikan dengan tumbuhnya semangat keterbukaan dalam profesi (professional transparacy), keluasan dan versifikasi layanan (service) dalam menunaikan tugas profesionalnya.

Dalam pandangan Islam kedudukan guru sangatlah tinggi dan Undang-Undang Sisdiknas No. 14 tahun 2005 mengatur tentang guru dari definisi, qualifikasi, Kompetensi, dan sertifikasi. Namun, kondisi pada saat ini masih jauh dari harapan yang diharapkan, penyebabnya berdasarkan tuturan para pakar seperti yang akan dijelaskan dibawah ini.

Rendahnya pengakuan masyarakat terhadap guru, menurut Nana Sudjana, disebabkan oleh beberapa faktor, yaitu:

1. Adanya pandangan sebagai masyarakat bahwa siapa pun menjadi guru, asalkan ia berpengetahuan, walaupun tidak mengerti didaktik-metodik.

2. Kekurangan tenaga guru di daerah terpencil memberikan peluang mengangkat seseorang yang tidak mempunyai kewenangan profesional untuk menjadi guru.

3. Banyak tenaga guru sendiri yang belum menghargai profesinya sendiri, apalagi berusaha mengembangkan profesi tersebut. Perasaan rendah diri karena menjadi guru masih menggelayut di hati mereka sehingga mereka melakukan penyalahgunaan profesi untuk kepuasan dan kepentingan pribadi, yang hanya akan menambah pudar wibawa guru di mata masyarakat (Tabarani Rusyan, 1992:2).

Menurut Ahmad Tafsir ada dua penyebab keterpengaruhan guru dan masyarakat oleh paham Barat. Pertama, karena menipisnya iman. Menipisnya 
iman ini tentu perlu dicari lagi penyebabnya. Maksudnya pahampaham tadi adalah salah satu kemungkinan-kemungkinannya. Kedua, karena kekaguman, katakanlah silau terhadap kemajuan sain dan teknologi Barat yang memang telah menghasilakan barang-barang yang memudahkan kehidupan di dunia ini. Kekaguman itu begitu hebatnya sampaisampai Muslim tidak lagi berkemampuan untuk menggunakan daya pilihnya; ia tidak mampu lagi mempungsikan filter-nya. Akhirnya muncul pandangan bahwa apa saja yang dari Barat, tentu baik.

Dengan daya filter yang lemah akhirya nilai-nilai Barat yang berlawanan dengan ajran Al-Qur`an dan Hadist, seperti tiga paham diatas (rasionalisme, materialism, dan pragmatism) cukup mampu menghancurkan nilai-nilai dasar Islam. Pengaruh paham itu yang akhirnya menjauhkan orang Islam dari akar budanyanya, untuk selanjutnya menyaksikan hasilnya dalam masyarakat Islam antara lain rendahnya guru dalam masyarakat Islam.

Dengan kondisi merosotnya pandangan terhadap kedudukan guru maka menurut peneliti perlu masyarakat dipahamkan tentang makna guru dan para gurupun memantaskan diri untuk layak menyandang titel guru.

Perlu diketahui bahwa guru adalah unsur manusia dalam pendidikan. Guru adalah figur manusia sumber yang menepati posisi dan memegang peranan penting dalam pendidikan. Ketika semua orang mempermasalahkan masalah dunia pendidikan, figur guru mesti terlibat dalam agenda pembicaraan, terutama dalam menyangkut persoalan pendidikan formal di sekolah. Hal itu tidak dapat disangkal, karena lembagan pendidikan formal adalah dunia kehidupan guru. Sebagian waktu guru ada di sekolah, sisanya ada di rumah dan di masyarakat.

Menjadi guru berdasarkan tuntutan pekerjaan adalah suatu perbuatan yang mudah, tetapi menjadi guru berdasarkan panggilan jiwa atau tuntutan hati nuarani adalah tidak mudah, karena kepadanya lebih banyak dituntut suatu pengabdian kepada anak didik dari pada kerena tuntutan pekerjaan dan material oriented. Guru yang mendasarkan pengabdiannya karena penggilan jiwa merasakan jiwanya lebih dekat dengan anak didiknya ketiadaan anak didiknya di 
kelas menjadi pemikirannya, kenapa anak didiknya tidak hadir di kelas. Apa penyebabnya, dan berbagai pertanyaan yang mungkin guru ajukan ketika itu.

Figur guru yang mulia adalah sosok guru yang dengan rela hati menyisihkan waktunya demi kepentingan anak didik, demi membingbing anak didik, mendengarkan keluhan anak didik, menasihati anak didik, membantu kesulitan anak didik dalam segala hal yang bisa menghambat segala aktifitasnya, merasakan kedukaan anak, bersama-sama dengan anak didik pada waktu senggang, berbicara dan bersenda gurau di sekolah, di luar jam kegiatan interaksi edukatif di kelas, bukan hanya duduk di kantor dengan dewan guru, dan membuat jarak dengan anak didik.

\section{B. Pembahasan}

\section{Pengertian Guru}

Secara etiomologi Guru adalah orang yang melakukan bimbingan. Pengertian ini memberikan kesan bahwa guru orang yang melakukan dalam pendidikan.

Dalam literatur kependidikan Islam, pendidikan bisa disebut sebagai berikut :
A) Ustadz yaitu seorang gutu dituntut untuk komitmen terhadap profesinya, ia selalu berusaha memperbaiki dan memperbaharui model-model atau acara kerjanya sesuai dengan tuntutan zaman.

B) $M u^{` a}$ alim, berasal dari kata dasar ilm yang berarti menangkap hakekat sesuatu. Ini mengandung makna bahwa guru adalah orang yang dituntut untuk mampu menjelaskan hakekat dalam pengetahuan yang diajarkan.

C) Murabby berasal dari kata dasar "rabb" tuhan sebagi Rabb al-alamin dan Rabb al-Nas yakni yang menciptakan, mengatur, dan memelihara alam seisinya termasuk manusia. Dilihat dari pengertian ini maka guru adalah orang yang mendidik dan menyiapkan peserta didik agar mampu berkreasi, sekaligus menatur dan memelihara hasil kreasi, sekaligus mengatur dan memelihara hasil kreasinya untuk tidak menimbulkan malapetaka bagi dirinya, masyarakat dan alam sekitar.

D) Mursyid yaitu seorang guru yang berusaha menularkan penghayatan (transinternalisasi) akhlak dan atau 
kepribadian kepada peserta didiknya.

E) Mudarris berasal dari kata darasayadrusu-darsan wadurusan wadirasatan yang berarti terhapus, hilang bekasnya, menghapus, melatih dan mempelajari. Arti guru adalah orang yang berusaha mencerdaskan peserta didiknya, menghilangkan ketidak tahuan atau memberantas kebodohan, serta melatih keterampilan peserta didik sesuai dengan bakat dan minatnya.

F) Mua ddih berasal dari kata adab, yang berarti moral, etika dan adab. Artinya guru adalah orang yang beradab sekaligus memiliki peran dan fungsi untuk membangun peradaban (civilization) yang berkualitas di masa depan. Di Indonesia pendidikan disebut juga guru (orang yang digugu dan ditiru).

Dalam kamus besar Bahasa Indonesia edisi ketiga 2001, guru diartikan sebagai orang yang pekerjaanya mengajar. Dalam Bahasa inggris disebut teacher yakni a person whose accuptionis teaching other (MC Leod. 1989) artinya guru adalah seseorang yang pekerjaanya mengajar orang lain.
Dalam pengertian yang sederhana, guru adalah orang yang memberi ilmu pengetahuan kepada anak didik. Guru dalam pandangan Masyarakat adalah orang yang melakukan pendidikan ditempat-tempat tertentu, tidak mesti di lembaga pendidikan formal, tetapi bisa juga di Mesjid, di surau/mushola, di rumah, dan sebagainya.

Guru adalah salah satu komponen manusiawi dalam proses belajar mengajar, yang sudah barang tentu ikut berperan dalam usaha pembentukan sumber daya manusia yang potensial di biadang pengembangan.

Guru adalah figur sentral dalam pendidikan Islam. Guru bertanggung jawab terhadap perkembangan anak didik dengan mengupayakan perkembangan seluruh potensi, baik potensi kognitif, efektif, maupun psikomotorik, guru profesional mempunyai kedudukan yang tinggi karena dapat mengantarkan anak didik menjadi insan kamil sehingga menuntut mereka untuk mengetahui dan memahami tugas dan kewajibannya sebagai guru yang pada akhirnya ia benar-benar mempu menunjukkan 


\section{Pemikiran Ahmad Tafsir tentang Guru:...(Jajang Badruzaman)}

peranannya di sekolah, di rumah dan di masyarakat.

Dalam literatur kependidikan Islam, istilah pendidikan mencakup pengertian ta`lim, tarbiyah, irsyad tadris, ta`dib, tazkiyah dan tilawah. Pendidiknya disebut ustad, mu`allim, murabbiy, mursyid, mudarris, mu`addib, muzakki.

A) Ustadz orang yang komitmen terhadap profesionalisme, yang melekat pada dirinya sikap dedikatif, komitmen terhadap mutu proses dan hasil kerja, serta sikap continuous improvement, ustadz bertugas untuk melakukan taklim, tarbiyah, irsyad, tadris, ta`dib, tazkiyah dan tilawah.

B) Taklim adalah upaya membentuk peserta didik agar mampu menangkap makna dibalik yang tersurat, mengembangkan pengetahuan serta menjelaskan fungsinya dalam kehidupan, baik secara teoritis maupun praktis, atau melakukan “transfer ilmu/pengetahuan, internalisasi, serta amaliah (implementasi) secara terpadu.

C) Tarbiyah adalah upaya membantu peserta didik agar mampu mengatur, mengembangkan, memperbaiki, dan meningkatkan dirinya dengan segala potensinya dan satuan sosial (dalam kehidupan masyarakat) secara bertahap ke tingkat yang lebih tinggi dan lebih baik.

D) Irsyad adalah upaya meningkatkan kualitas akhlak kepribadian peserta didik atau upaya pemberian keteladanan.

E) Tadris adalah upaya mencerdaskan peserta didik, memberantas kebodohan mereka, serta melatih keterampilan sesuai dengan bakat, minat dan kemampuannya sehingga menjadi tenaga yang produktif.

F) Ta`dib adalah upaya menyiapkan peserta didik untuk bertanggung jawab dalam membangun peradaban yang berkualitas di masa depan.

G) Tadzkiyah adalah upaya menyucikan jiwa peserta didik sehingga ia kembali kepada fitrahnya.

H) Tilawah adalah upaya pewarisan nilai-nilai ilahi dan nilai-nilai insani kepada peserta didik. 


\section{Syarat Guru dalam Pendidikan Islami}

Untuk menjadi seorang guru tidaklah mudah seperti yang dibayangkan orang selama ini. Mereka menganggap hanya dengan pegangan kapur dan membaca buku pelajaran, maka cukup bagi mereka untuk berprofesi sebagai guru.

Soejono, menyatakan bahwa syarat guru adalah sebagai berikut:

A) Tentang umur, harus sudah dewasa

Tugas mendidik adalah tugas yang amat penting kaena menyangkut perkembangan seseorang, jadi menyangkut nasib seseorang. Oleh karena itu, tugas itu harus dilakukan secara bertanggung jawab. Itu hanya dapat dilakukan oleh orang telah dewasa; anak-anak tidak dapat diminta pertanggungjawaban.

Di Negara kita, seseorang dianggap dewasa seja ia berumur 18 tahun atau sudah kawin. Menurut ilmu pendidikan adalah 21 tahun bagi lakilaki dan 18 tahun bagi perempuan. Bagi pendidik asli, yaitu orang tua anak, maka mereka boleh mendidik anaknya. Dilihat dari segi ini, sebaiknya umur kawin adalah 21 bagi lelaki dan minimal 18 bagi perempuan
B) Tentang kesehatan, harus sehat jasmani dan rohani Jasmani yang tidak sehat akan menghambat pelaksanaan pendidikan, bahkan dapat membahayakan anak didik bila mempunyai penyakit menular. Dari segi ruhi. Orang gila berbahaya juga bila ia mendidik. Orang idiot tidak mungkin mendidik karena ia tidak akan mampu bertanggungjawab.

C) Tentang kemampuan mengajar, ia harus ahli

Ini penting sekali bagi pendidik, termasuk guru (orang tua di rumah sebenarnya perlu sekali mempelajari teori-teori ilmu pendidikan. Dengan pengetahuan itu diharapkan ia akan lebih berkemampuan menyelenggarakan pendidikan bagi anak-anak di rumahnya. Seirngkali terjadi kelainan pada anak didik disebabkan oleh kesalahan pendidikan di dalam rumah tangga.

D) Harus berkesesuaian dan berdedikasi tinggi

Syarat ini amat penting dimiliki untuk melaksanakan tugas-tugas mendidik selain mengajar. Bagaimana guru akan memberikan contoh-contoh kebaikan bila ia sendiri tidak baik peranginya ? Dedikasi tinggi tidak hanya diperlukan dalam mendidik selain 


\section{Pemikiran Ahmad Tafsir tentang Guru:...(Jajang Badruzaman)}

mengajar; dedikasi tinggi diperlukan juga dalam meningkatkan mutu mengajar.

Syarat-syarat itu adalah syaratsyarat guru pada umumnya, syaratsyarat itu dapat diterima dalam Islam. Akan tetapi, mengenai syarat pada butir dua, yaitu tentang kesehatan jasmani, Islam dapat menerima guru yang cacat jasmani tetapi sehat. Untuk guru di perguruan tinggi, misalnya, orang buta atau cacat jasmani lainnya dapat diterima sebagai tenaga pengajar asal cacat itu tidak merintangi tugasnya dalam mengajar.

Munir Mursi, tatkala membicarakan syarat guru kuttab (semacam sekolah dasar di Indonesia), menyatakan syarat terpenting bagi guru dalam Islam adalah syarat keagaman. Dengan demikian, syarat guru adalah Islam adalah sebagai berikut:

A) Umur, harus sudah dewasa;

B) Kesehatan, harus sehat jasmani dan ruhani;

C) Keahlian, harus menguasai bidang yang diajarkannya dan menguasai ilmu mendidik (termasuk ilmu pengetahuan);

D) Harus berkepribadian Muslim.

Secara operasional, syarat umur dapat dibuktikan memperlihatkan akte kelahiran atau tanda pengenal sah lainnya; syarat kesehatan dibuktikan dengan memperlihatkan keteranagan dokter; syarat keahlian dapat dilihat pada ijazah atau keterangan sah lainnya; dan syarat agama secara sederhana dapat dibuktikan dengan memperlihatkan kartu penduduk atau keterangan lainnya.

Syarat-syarat yang pokok yang dimiliki oleh seorang guru menurut Sulani, adalah:

A) Syarat syahsiyah (memiliki kepribadian yang dapat diandalkan)

B) Syarat ilmiyah ( memiliki ilmu pengetahuan yang mumpuni)

C) Syarat Idhofiyah (mengetahui, menghayati dan menyelami manusia yang dihadapinya, sehingga dapat menyatukan dirinya untuk membawa anak didik menuju tujuan yang ditetapkan).

Guru dalam Islam sebagai pemegang jabatan professional membawa misi ganda dalam waktu yang bersamaan, yaitu misi agama dan misi ilmu pengetahuan. Misi agama menuntuk guru untuk menyampaikan nilai-nilai ajaran agama kepada anak didik, sehingga anak didik dapat menjalankan kehidupan sesuai dengan 
norma-norma agama tersebut. Misi ilmu pengetahuan menuntut guru menyampaikan ilmu sesuai dengan perkembangan zaman.

Untuk mewujudkan misi ini, menurut Ghofir yang dikutip oleh Agus Maimun, guru harus memiliki seperangkat kemampuan, sikap dan keterampilan berikut;
A) Landasan moral yang kukuh untuk melakukan "jihad" dasn mengemban amanah.
B) Kememampuan mengembangkan jaringan-jaringan kerja sama atau silaturahmi.
C) Membentuk team work yang kompak.
D) Mencintai kualitas yang tinggi.

Untuk menjadi guru agama ada beberapa persyaratan yang harus dimiliki yaitu:

A) Syarat Fisik

Persyaratan fisik ini antara lain, meliputi berbadan sehat, tidak memiliki cacat tubuh yang mengganggu pekerjaanya (seperti mata, telinga, cacat tangan dsb.) tidak memiliki gejala-gejala penyakit yang menular, seorang guru yang berpenyakit menular akan membahayakan peserta didiknya dan membawa akibat tidak baik dalam tugasnya sebagai guru.

B) Syarat Psikis

Yang berkaitan dengan kelompok persyaratan psikis adalah sehata rohani, dewasa dalam berpikir dan bertindak, mampu mengendalikan emosi, sabar, ramah dan sopan, memiliki jiwa kepemimpinan, konsekuen dan berani bertanggungjawab, berani berkorban dan memiliki jiwa pengabdian. Disamping itu juga guru dituntut untuk bersifat pargmatis dan realistis. Guru harus juga mematuhi norma dan nilai yang berlaku serta memiliki semangat membangun. Inilah pentingnya bahwa guru harus memiliki rasa keikhlasan yang tinggi terhadap pelaksanaan proses pembelajaran.

C) Syarat Keagamaan

Seorang pendidik harus seorang yang beragama dan mengamalkan ajaran agamanya. Disamping itu ia menjadi figure identifikasi dalam segala aspek kepribadiannya. la menjadi sumber norma dari segala norama agama yang dianutnya. la menjauhkan diri dari segala sifat yang tercela dan menghiasi dirinya dengan segala sifat yang terpuji.

D) Syarat Teknis 
Seorang pendidik harus memiliki ijazah pendidikan guru seperti ijazah fakultas IImu Pendidikan. Fakultas Tarbiyah atay ijazah keguruan lainya. ljazah tersebut harus disesuaikan dengan tingkatan lembaga pendidikan tempat ia mengajar.

E) Syarat Pedagogis

Seorang pendidik harus menguasai metode mengajar, menguasai materi yang akan diajarkan dan ilmuilmu lain yang ada hubungannya dengan ilmu yang ia ajarkan. la harus juga mengetahui psikologi, terutama psikologi peserta didik dan psikologi pendidikan agar ia dapat menempatkan diri dalam kehidupan peserta didi dan memberikan bimbingan sesuai dengan perkembangan peserta didik.

F) Syarat Administratif

Seorang pendidik harus diangkat oleh pemerintah, yayasan atau lembaga lain yang berwenang mengangkat guru sehingga ia diberi tugas untuk mendidik dan mengajar. Degnawn diangkatnya ia sebagai pendidikan/guru maka ia harus mencintai tugasnya dan mengbdikan diri kepada tugs yang diembannya.

G) Syarat Umur

Seorang pendidik haruslah seorang dewasa. Dalam Islam kedewasaan itu disebutkan akil balig, atau mukallaf.

\section{Sifat Guru dalam Pandangan Islam}

Menuru M. Ngalim Purwanto, MP adalah sebagai berikut
A) Adil (tidak membedakan dan pilih kasih)
B) Percaya dan suka (senang) kepada murid-muridnya.
C) Sabar dan rela berkorban
D) Memiliki wibawa terhadap anak didiknya.

E) Pengembira (humoris, supaya memikat anak/peserta didik ketika mengajar).
F) Bersikap baik terhadap guru-guru lainya.

G) Bersikap baik terhadap masyarakat.
H) Benar-benar menguasai mata pelajarannya.

I) Suka kepada mata pelajaran yang diberikannya.

J) Berpengetahuan luas.

Kewibawaan dalam masyarakat dibedakan menjadi tiga macam diantranya
A) Kewibawaan legal.
B) Kewibawaaan serba-tradisi.
C) Kewibawaan kharismatik.
Teori melihat kewibawaanada yang berdasarkan pada: 
A) Teknik, kewibawaan teknis diperoleh karena keahlian yang khusus. Contoh seorang guru karena dia mempunyai keahlian khusus, yaitu mengajar, sehingga dia mempunyai kewibawaan di depan anak didiknya.

B) Moral, kewibawaan yang didasarkank pada prinsip moralitas. Atau dalam Bahasa agama adalah akhlak. Akhlak juga terbagi ke dalam dua bagian, yaitu: akhlak mahmudah (akhlak yang baik), dsan akhlak madzmu`mah (akhlak yang jelek)

C) Pribadi, kewibawaan pribadi, yaitu yang berasal dari kepribadian seseorang.

Al-Abrasyi, menyebutkan bahwa guru dalam Islam sebaiknya memiliki sifat-sifat sebagi berikut ini;

A) Zuhud, tidak mengutamakan materi, mengajar dilakukan karena mencari keridhoan Alloh 艦.

B) Bersih tubuhnya: jadi, penampilan lahiriyah menyenangkan

C) Bersih jiwanya: tidak mempunyai dosa besar

D) Tidak ria: ria akan menghilangkan keikhlasan

E) Tidak memendam rasa dengki dasn iri hati
F) Tidak menyenangi permusuhan

G) Ikhlas dalam melaksanakan tugas

H) Sesuai perubahan dan perkataan

I) Tidak malu mengakui ketidaktahuan

J) Bijaksana

K) Rendah hati (tidak sombong)

L) Lemah lembut

M) Pemaaf

N) Sabar, tidak marah karena hal-hal kecil

O) Berkepribadian

P) Tidak merasa rendah diri

Q) Bersifat kebapakan (mampu mencintai murid seperti mencintai anak sendiri

R) Mengetahui karakter murid, mencakup pembawaan, kebiasaan, perasaan, dan pemikiran.

Menuru Ahmad Tafsir, Al-Abrasyi kelihatanya berusaha merinci ciri-ciri guru yang ideal. Dalam merinci itu jelas acuaanya adalah ciri-ciri muslim yang paripurna. la tidak dapat berhasil membuat rincin, seperti diatas. Ketidakberhasilan itu terutama kelihatan pada banyak terjadi tumpeng tindih antara satu sifat dengan sifat lainnya. Misalnya saja sifat berkepribadian; sifat ini tumpeng tindih dengan sifat sabar, tidak merasa rendah dirim dan sebagainya, masih juga perlu diuji, apakah butir-buti itu telah benar-benar 
Pemikiran Ahmad Tafsir tentang Guru:...(Jajang Badruzaman)

mencakup seluru ciri kepribadian Muslim paripurna.

\section{Tugas Guru}

Guru adalah manusia yang memiliki kepribadian sebagai individu. Kepribadian guru, seperti halnya kepribadian individu pada umumnya terdiri atas aspek jasmaniah, intelektual, social, emosional, dan moral. Seluruh aspek kepribadian tersebut terintegrasi membentuk satu kesatuan yang utuh, yang memiliki ciri-ciri yang khas. Integritas dan kehasan ciri-ciri individu tersebut sepanjang perkembangan hidupnya, yang merupakan hasil perpaduan dari ciri-ciri dan kemampuan bawaan dengan perolehan dari lingkuangan dan pengalaman hidupnya.

Menurut Madyo Ekosusilo, yang dimaksud dengan guru atau pendidik adalah seorang yang bertanggung jawab untuk memberikan bimbingan secara sadar terhadap perkembangan kepribadian dan kemampuan peserta didik baik dari aspek jasmani maupun rohaninya agar ia mampu hidup mandiri dan dapat memenuhi tugasnya sebagai makhluk tuhan sebagai individu dan juga sebagai makhluk social.

Di dalam undang-undang RI No. 20 Tahun 2003 tentang system
Pendidikan Nasional, Bab IV pasal 29 ayat 1 disebutkan bahwa pendidik merupakan tenaga professional yang bertugas merencanakan dan melaksanakan proses pembelajaran, memiliki hasil pembelajaran melakukan pembimbingan dan pelatihan serta melakukan penelitian dan pengabdian kepada masyarakat, terutama pada pendidikan di perguruan tinggi.

Kata Profesi identik juga dengan kata keahlian, demikian juga Jarvis (1983) mengartikan seseorang yang melakukan tugas profesi juga sebagai seorang ahli (expert). Pada sisi lain profesi mempunyai pengertian sesorang yang menekuni pekerjaan berdasarkan keahlian, kemampuan, teknik, dan prosedur berdasarkan intelektualitas. Hal demikian dapat dibaca pula pendapat Volmer dan Mills (1966), Mc Cully (1969), dan Diana W. Kommer (dalam Sanggala, 2000: 195-196), mereka sama-sama mengartikan profesi sebgai spesialisasi dari jabatan intelektual yang diperoleh melalui studi dan training, bertujuan menciptakan keterampilan, pekerjaan yang berniali tinggi, sehingga keterampilan dan pekertjaan itu diminati, disenangi oleh orang lain, dan dia dapat melakukan pekerjaan itu dengan mendapatkan 
imbalan berupa bayaran, upah, dan gaji (payment).

Dari pemahaman istilah pendidikan tersebut, maka tugas guru dalam perspektif pendidikan Islam adalah sebagai berikut:

\section{A) Mengembangkan}

perofesionalismenya

secara

berkelanjutan dalam melakukan ta`lim, tarbiyah, irsyad, tadris, ta`dib, tazkiyah, dan tilawah.

B) Mengembangkan pengetahuan teoritis, praktis, dan fungsional sebagai peserta didik;

C) Menumbuhkembangkan krativitas, potensi-potensi dan atau fitarah peserta didik

D) Meningkatkan kualitas akhlak dan kepribadian, dana tau menumbuh kembangkan nilai-nilai insani dan nilai-nilai ilahi;

E) Menyiapkan tenaga kerja yang produktif.

F) Membangun peradaban yang berkualitas (sesuai dengan nilai-nilai Islam) di masa depan;

G) Membantu peserta didik dalam penyucian jiwa sehingga ia kembali kepada fitrahnya;

H) Mewariskan nilai-nilai ilhi dan nilainilai insani kepada peserta didik.

\section{Guru Profesional}

Rasulullah pernah bersabda (dalam Assayuti, hal; 36) bahwa " suatu pekerjaan yang diserahkan pada seseorang bukan profesinya, maka tunggulah kehancurannya” (HR.Bukhari).

Profesi identik juga dengan keahlian, demikian juga Jarvis (1983) mengartikan seseorang yang melakukan profesi juga sebagai seorang yang ahli (expert). Pada sisi lain profesi mempunyai pengertian seseoran yang menekuni pekerjaan berdasarkan keahlian, kemampuan, teknik, dan prosedur berdasarkan intelektualitas. Hal demikian dapat dibaca pula pendapat Volmer dan Milis (1966), Mc Cully (1969) dan Diana W. Kommers (dalam Sagala, 2000: 195-196), mereka sama-sama mengartikan profesi sebagai spesialisai dari jabatan intelektual yang diperoleh melalui studi dan training, bertujuan menciptakan keterampilan, pekerjaan yang bernilai tinggi, sehingga keterampilan dan pekerjaan itu diminati, disenangi oleh orang lain, dan dia dapat melakukan pekerjaanitu dengan mendapatkan imbalan berupa bayaran, upah, dan gajih (Payment).

Meminjam kuadralitas Rober $\mathrm{T}$. Kiyosaki, guru dibagi menjadi 4 


\section{Pemikiran Ahmad Tafsir tentang Guru:...(Jajang Badruzaman)}

kuadaran berdasarkan mentalitas kerja. Kuadaran pertama, guru pekerja, guru ini diposisi yang paling rendah karena mentalitasnya masih sekedar tuntutan kerja. Guru Pekerja adalah guru yang pergi tepat waktu. Pulang tepat waktu. Lebih parah lagi, kalau guru itu datang terlambat dan pulang cepat. Guru yang mengajar hanya sebatas tugas ataupun kerja belaka, tidak memiliki visi kedepan untuk membangun pendidikan yang lebih baik. Kuadarn kedua, yaituGuru professional. Guru Profesional adalah guru yang telah memiliki keterempilan dalam mengajar dengan baik sehingga guru ini dihargai oleh banyak orang. la sudah mengubah dirinya menjadi guru yang mempunyai "harga" dan harga diri yang dihormati orang. Misalnya, seorang guru professional disuruh untuk mengajar di sebuah sekolah atau yayasan, kemudian ia dapat menjawab, "berani berapa membayar saya untuk mengajar di sekolah atau yayasan anda" Guru professional, guru yang sudah di "hargai” oleh orang lain.

Kuadaran ketiga, guru pemilik, guru di kuadran ini sudah sangat professional dan dirinya merasa memiliki sekolah. Dengan penuh semangat pengabdiannya terhadap dunia pendidikan ia menghabiskan sebagai

waktunya

unutk mengembangkan pendidikan di sekolah tersebut. Bagi Guru Pemiliki seluruh jiwa dan raganya dipersembahkan untuk kemajuan sekolah di mana ia ditugaskan demi membantu untuk mencerdaskan anak-anak bangsa. Kuadaran keempat, Guru Perancang, guru tipe ini memiliki mentalitas yang luar biasa. Guru Perancang sangat memahami mana profesinya. Memiliki visi untuk mencerdaskan anak-anak bangsa. la mendidik dan merancang metode pengajaran dengan kreatif agar bisa dinikmati oleh seluruh guru di Indonesia. Guru Perancang inilah, mentalitas guru yang sanggup merubah diri seseorang guru menjadi lebih elegant dan bermartabat di depan siapapun. Guru Perancang merupakan guru kreatif, penuh dengan inovasiinovasi baru dalam dunia pendidikan dan pembelajaran. Pemikiran-pemikiran ia tuangkan dalam bentuk tulisan, buku, ataupun konsep-konsep yang lain dalam membangun pendidikan kearah yang lebih baik.

Guru Profesional adalah yang mampu menerapkan hubungan yang bentuk multidimensional. Guru yang demikian adalah guru yang secara 
internal memenuhi kriteria administrasi, akademis, dan kepribadian.

Khususnya dalam perpektif Pendidikan Islam persyaratan guru professional adalah sehat jasmani dan ruhani, bertaqwa, berilmu pengetahuan, berlaku adil, berwibawa, ikhlash, mempunyai tujuan Rabbani, mampu merencanakan dan melaksanakan evaluasi pendidikan. Serta menguasai bidang yang ditekuni. Tetapi secara gars besar dapat dikelompokann ke dalam tiga katagori. Yaitu persyaratan administrative, akademis, dan kepribadian. Yang pertama, Persyaratan administrafit, persyaratan ini berhubungan dengan legal formal. $\mathrm{Di}$ Indonesia hal ini sangat mentukan bahkan kualitas seseorang dapat dilihat dari ijazah serta sertifikat keilmuan yang dimilikinya. Dalam konteks ke Indonesiaan persyaratan administrative merupakan salah satu syarat yang penting. Kedua, Persyaratan akademis, kesuksesan pendidikan bukan hanya menjadi beban dan tanggung jawab pencari ilmu, akan tetapi justru gurulah yang mem yang memegang peran dominan. Persyartan akademis ini sangat menentukan keberhasilan pendidikan yang dilaksanakanya akerena hal ini berhubungan dengan kapabilitas dan kualitas intelektualitas seorang guru. Ketiga, persyaratan kepribadian, syarat ini berhubungan dengan sikap dan perilaku dalam kehidupan sehari-hari. Sebagaimana ungkapan bahwa guru adalah seorang yang harus digugu dan ditiru, khususnya oleh murid. Dengan hal ini guru harus memiliki kepribadian dan prilaku yang baik, dalam hal ini bukan hanya dalam kaitanya dengan tradisi, kesopanan, dan ungah-unguh di masyarakat setempat, akan tetapi juga nilai-nilai keagamaan Islam. Seperti berakhlak yang mulia, baik dalam ketaatannya dengan orang lain (murid dan masyarakat), diri sendiri, lingkungan (alam sekitar), dan tentunya dengan Allah 然.

Ketiga katagori persyaratan tersebut tidak dipahami secara parsial atau terpisah antara satu dengan yang lainnya, melainkan harus disinegikan diantara ketiganya. Jadi kesimpulanya guru professional adalah guru yang secara administrative, akademis, dan kepribadian telah memenuhi persyartan dalam bentuk hubungan multidimensional dengan muridnya. Hubungan antar guru dan murid dalam bentuk hubungan multidimensional harus terwujud bersamaan dengan 


\section{Pemikiran Ahmad Tafsir tentang Guru:...(Jajang Badruzaman)}

terpenuhinya ketiga katagori perysaratan tersebut.

Dalam pandangan lain guru dalam Islam adalah orang yang bertanggung jawab terhadap perkembangan anak didik dengan mengupayakan seluruh potensinya, baik potensi afektif, kognitif, maupun potensi psikomotorik. Guru juga berarti dewasa yang bertanggu jawab memberikan pertolongan pada anak didik dalam perkembangan jasmani dan ruhainya agar mencapai tingkat kedewasaan, serta mampu berdiri sendiri dalam memenuhi tugas sebagai hamba Alloh 登.

Tiga ciri kedewasaan diantarnya Pertama, memiliki tujuan dan pedoman hidup (philosophy of life) yaitu sekumpulan nilai yang ia yakini kebenarannya dan menjadi pedoman dan pegangan dalam hidupnya, sehingga hidupnya punya prinsip dan tidak mudah terombang ambing, teguh dalam dalam pendirianya. Kedua, mampu melihat sesuatu secara objektif, tidak banyak dipengaruhi oleh objektifitas dirinya. Mampu melihat dirinya dan orang lain secara objektif, melihat kelebihan dan kekurangan dirinya dan juga orang lain, lebih dari itu ia mampu bertindak sesuai dengan hasil penglihatannya tersebut.
Ketiga, telah bisa bertanggung jawab. Memiliki kemerdekaan, kebebasan; tetapi sisi lain dari kebebasan adalah tanggung jawab. Dia bebas menentukan arah hidupnya, perbuatanya, tetapi setalah berbuat ia dituntut tanggung jawab.

Oemar Hamakil dalam bukunya Proses Belajar Mengajar (2001; 118), guru professional haru memiliki persyaratan, yang meliputi;
A) Memiliki bakat sebagai guru.
B) Memiliki keahlian sebagai guru.
C) Memiliki keahlian yang baik dan terintegrasi.
D) Memiliki mental yang sehat.
E) Berbadan sehat.
F) Memiliki pengalaman dan pengetahuan yang luas.

G) Guru Adalah manusia berjiwa Pancasial.

H) Guru Adalah seorang warga negara yang baik.

I) Kriteria Profesi Menurut Ahli

Menurut Glenn Langford, kriteria Profesi mencakup; (1) upah, (2) memiliki kemampuan dan keterampilan, memiliki rasa tangggungjawab dan tujuan, (4) mengutamakan layanan, (5) memiliki kesatuan, (6) mendapatkan pengakuan dari orang lain atas pekerjaan yang digelutinya. Keriteria ini 
akan menjadi pembahasan berikut ini, masing-masing kriteria di atas saling terkait antar satu dengan yang lainnya. Rusak salah satu kriteria maka suatu pekerjaan itu tidak dapat daikatan professional. Selanjutnya penulis mengaitkan pekrjaan guru dengan kriteria di atas ini, apakah sudah termasuk professional? Atau sebatas jargon?, beberapa ahli berpendapat bahwa pekerjaan guru adalah sebagai profesi, akan tetapi masih ada sebagian pakar memprtanyakan profesi guru suatu jargoan, sebab pekerjaan guru sering dilihat dari sebalah mata dana dinina bobokan dengan pangkat guru pahlawan tanpa jasa , tanpa menghiraukan problem yang dihadapi guru, yaitu peningkatan kualitas, kesejahtraan, dan diskriminasi guru.

Moore mengidentifikasi profesi menurut ciri-ciri berikut;

Seseorang Profesional menggunakan waktu penuh untuk menjalankan pekerjaanya.

A) la terikat oleh panggilan hidup, dan dalam hal ini memprlakukan pekerjaanya sebagai seperangkat norma kepatuhan dan perilaku.

B) la anggota organisasi professional yang formal.
C) la menguasai pengetahuan yang berguna dan keterampilan atas dasar latihan spesialisasi atau pendidikan yang sangat khusus.

D) la terikat dengan syarat-syarat kompetensi, kesadaran prestasi, dsan pengambdian.

E) la memperoleh otonomi berdasarkan spesialisasi teknis yang tinggi sekali.

Green wood (dalam Vollmer, 1956, 10-19) menyarankan bahwa profesi-profesi dibedakan dari non profesi karena memiliki unsur yang asensi berikut;

A) Suatu dasar teori sistematis

B) Kewenangan (authority) yang diakui oleh klien

C) Sanksi dan pengakuan masyarkat atas kewenangan ini.

D) Kode etik yang mengatur hubunganhubungan dari orang-orang perfesional dengan klien dan teman sejawat; dan

E) Kebudayaan profesi yang terdiri atas nilai-nilai, norma-norma dan lembaga-lembaga.

Komisi kebijaksanaan NEA Amerika Serikat, menyebutkan kreteria profesi daslam bidang Pendidikan, sebagai berikut; 
A) Profesi didasarkan atas sejumlah pengetahuan yang dikhususkan,

B) Profesi mengajar kemajuan dalam kemampuan para anggotanya.

C) Profesi melayani kebutuhan para anggotanya (akan kesejahtraan dan pertumbuhan professional)

D) Profesi memiliki norma-norma etis.

E) Profesi mempengaruhi kebijaksanaan pemerintah di bidangnya (mengenai perubahanperubaha dalam kurikulum, struktur organisasi pendidikan, persiapan professional, dst.)

F) Profesi memiliki solidaritas kelompok profesi.

Formulasi-formulasi tentang kriteria profesi tersebut di atas, walaupun dalam kata-kata yang berbeda, pada hakekatnya memperlihatkan persamaan yang besar dalam subtansinya.

Khusunya di Indonesia ada istilah Guru pahlawan Tanpa Tanda Jasa. Istialh ini adalah suatu gelar yang melekat pada guru adalah seseorang “pahlawan tanpa tanda jasa”, gelar ini tidak semua guru dapat menerimanya, sebab gelar ini mungkin suatu penghormatan yang berat disandang, atau boleh saja gelar ini merupakan jargoan untuk guru, secara logika kita tentu bertanya, apakah ada seorang pahlawan yang tidak pakai tanda jasa? Sedangkan guru adalah seorang professional, artinya guru menyediakan jasa, akan tetapi jasa guru tidak dapat diakui, apa mungkin seseorang dapat berbuat maksimal tanpa pernah tahu menahu dengan kebutuhan hidupnya, rasanya tidak mungkin. Guru boleh saja ikhlas dalam mengemban tugas mengajar, akan tetapi mereka perlu memikirkan ekonomi, kesejahtraan keluarga, dan dirinya sendiri.

Pahlawan menurut W.J.S. Poewadarminta dalam Kamus Bahasa Indonesia (1983; 693) adalah orang yang gagah berani, atau terkemuka. Sedangkan pahlawan dalam pendapat lain mengatakan seseorang pejuang dalam memperjuangkan negaranya dari penjajahan dan ikut memperjuangkan kemerdekaan, ketertindasan dari kompeni dan juga ia meninggal disebut dengan pahlawan. Manakala kita memperjuangkan yang dilakukan guru adalah memerangi kebodohan, kejahilan, bukan dalam bentuk pertemuan yang dilakukan pejuang dalam merebut kemerdekaan, dan mengusir penjajahan, akan tetapi perjuangan dalam memerangi kebodohan yang tidak dapat dilakukan 
oleh guru semata akan tetapi bersamasama masyarakat, dan orang tua.

\section{Guru dalam Perspektif Undang- undang Sisdiknas}

\section{A) Pengertian Undang-undang Sisdiknas}

Undang-Undang Sisdiknas adalah peraturan pemerintah dan pereturan mentri pendidikan nasional, yang mengatur Tentang System Pendidikan Nasional (Sisdiknas).

Di dalam pembukaan UUD 1945 disebutkan bahwa, untuk membentuk suatu pemerintah negara Indonesia yang melindungi segenap bangsa Indonesia dan seluruh tumpah dara Indonesia dan untuk memajukan kesejahtraan umum, mencerdaskan kehidupan bangsa, dan ikut melaksanakan ketertiban dunia yang berdasarkan kemerdekaan, perdamaian abadi dan keadilan social, maka disusunlah kemerdekaan kebangsaan Indonesia itu dalam suatu Undang-Undang Dasar Negara Indonesia, yang terbentuk dalam suatu susunan Negara Republik Indonesia yang berkedaulatan rakyat dengan berdasarkan kepada ketuhanan yang Maha Esa, kemanusiaan yang adil dan beradab, persatuan Indonesia dan kerakyatan yang dipimpin oleh hikmat kebijaksanaan dalam permusyawaratan/perwakilan, serta dalam mewujudkan suatu keadilan social bagi seluruh rakyat Indonesia.

Pendidikan nasional berdasasrkan Pancasila bertujuan untuk meningkatkan kualitas manusia Indonesia, yaitu manusia yang beriman dan bertaqwa terhadap tuhan yang maha Esa, berbudi pekerti yang luhur, berkepribadian, berdisiplin, bekerja keras, tangguh, bertanggung jawab, mandiri, cerdas dan terampil serta jasmani dan rohani. Pendidikan Nasionla juga harus mampu menumbuhkan dan memperdalam rasa cinta pada tanah air, mempertebal dan memperdalam rasa cinta pada tanah air, mempertebal semangat kebangsaan dan rasa kesetiakawanan social. Sejalan dengan itu dikembangkan iklim belajar dan mengajar yang dapat menumbuhkan rasa percaraya diri sendiri serta sikap dan prilaku yang inovatif dan kreatif. Dengan demikian pendidikan Nasional Akan mampu mewujudkan manusia-manusia pembangunan yang dapat membangun diri sendiri serta bersama-sama bertanggung jawab atas pembangunan bangsa. 
B) Kompetensi Guru

Secara harfiah kompetensi adalah suatu kecakapan yang diperlukan dalam melaksanakan suatu pekerjaan. Karena demikian banyaknya bidang pekerjaan yang harus dilakukan, maka kompetensi yang diperlukan makin beragam. Sedangakan tenaga pendidik adalah mereka yang kompetensinya yang khas menyebabkan ia mendapatkan kewenangan dalam melaksanakan tugas pendidikan.

Kompetensi adalah seperangkat pengetahuan, keterampilan, dan perilaku yang harus dimiliki, dihayati, dan dikuasai oleh guru.

Kompetensi adalah benih-benih kemampuan yang senantiasa dipupuk dann disiram melalui berbagai proses pembekalan dan penelitian, menekuni pekerjaan dengan sunguh-sunguh dan mengatasinya dengan berbagai cara bahkan berani mengambil resiko untuk menghadapi tantangan.

Undang-undang Nomor 14 tahun 2005 tentang Guru dan Dosen memuat berbagai aspek yang berkenaan dengan guru, mulai dari syarat yang harus dipenuhi untuk menunjang profesi guru meliputi kualifikasi, kompetensi, dan sertifikasi, sampai pada berbagai kemaslahatan yang berhak diterima guru dan kode etik yang harus dijaga.

Berbagai syarat harus dimiliki oleh seorang guru professional. $\mathrm{Hal}$ inilah yang pertama kali menentukan keberhasilan proses pendidikan. Dalam pasal 8 disebutkan bahwa guru wajib memiliki kualifikasi akademik, kompetensi, sertifikat pendidik, sehat jasmani dan rohani serta memiliki kemampuan untuk mewujudkan tujuan pendidikan nasional. Dalam Undangundang ini juga disebutkan bahwa kompetensi yang harus dimiliki oleh guru mencakup empat hal, yaitu kompetensi profesional, kompetensi pedagogik, kompetensi kepribadian, dan kompetensi sosial.

Penjelasan pasal 28 ayat 3 dikemukakan bahwa kompetensi pedagogic adalah kemampuan mengelola pembelajaran peserta didik. Secara pedagogis, kompetensi guru dalam mengelola pembelajaran perlu mendapat perhatian yang serius. Hal ini penting, karena pendidikan di Indonesia dinyatakan kurang berhasil oleh sebagian masyarakat. Proses pembelajaran di sekolah nampak sebagai proses mekanis yang kering aspek pedagogis atau yang biasa disebut sebagai pendidikan Gaya bank. 
Dengan model pendidikan tersebut, peserta didik menjadi kerdil, pasif, dan tidak dapat berkembang secara optimal karena pilihan-pilihannya cenderung dipaksakan oleh guru (berpusat pada guru). Padahal sebagai agen pembelajaran, guru tidak hanya bertugas dalam transformasi ilmu pengetahuan saja, tetapi ia juga harus berperan sebagai fasilitator, motivator, pemacu, dan inspirator bagi peserta didik.

Kompetensi professional adalah kemampuan penguasaan materi pembelajaran secara luas dan mendalam yang memungkinkan membimbing peserta didik memenuhi standar kompetensi yang ditetapkan dalam Standar Nasional Pendidikan.

Kompetensi kepribadian adalah kemampuan kepribadian yang mantap, berakhlak mulia, arif, dan berwibawa, serta menjadi teladan bagi peserta didik. Sedangkan kompetensi sosial adalah kemampuan guru untuk berkomunikasi dan berinteraksi secara efektif dan efisien dengan peserta didik, sesama guru, orang tua/wali peserta didik, dan masyarakat sekitar. Hal ini penting mengingat pribadi guru juga sangat berperan dalam membentuk pribadi peserta didik.
Menurut Syed Sajjad Husein, dalam Islam, guru harus merupakan pribadi yang dapat dijadikan teladan sehingga perilakunya dapat mempengaruhi peserta didik. Guru tidak hanya mengurusi materi pembelajaran; apa yang dilakukan, caranya berperilaku, sikapnya di dalam dan di luar kelas harus mampu membiuskan nilai yang dapat diterima oleh peserta didik. Hal ini lah yang menurutnya telah hilang dari kepribadian guru saat ini.

Karena sedemikian baanyak kompetensi yang harus dimiliki oleh guru sehingga pemerintah menetapkan diwajibkannya guru mengikuti proses sertifikasi dan uji kompetensi. Pasal 8 menyebutkan : "Guru wajib memiliki kualifikasi akademik, kompetensi, sertifikat pendidik, sehat jasmani dan rohani, serta memiliki kemampuan untuk mewujudkan tujuan pendidikan nasional". Untuk menjamin dilaksanakannya sertifikasi maka pemerintah (pusat) dan pemerintah daerah wajib menyediakan anggaran untuk peningkatan kualifikasi dan sertifikasi pendidik bagi semua guru, baik guru yang diangkat oleh satuan pendidikan yang diselenggarakan oleh pemerintah maupun oleh masyarakat (Pasal 13). 


\section{Pemikiran Ahmad Tafsir tentang Guru:...(Jajang Badruzaman)}

Guru yang telah memenuhi syarat tersebut maka ia akan lebih mudah menjalankan kewajiban-kewajibannya sebagaimana tertera dalam pasal 20 yaitu berkenaan dengan perencanaan sampai evaluasi pembelajaran, meningkatkan kualifikasi dan kompetensinya seiring perkembangan zaman, dan menjaga obyektivitasnya terhadap peserta didik.

Jika seluruh syarat dan kewajiban telah terpenuhi maka guru berhak mendapatkan berbagai fasilitas gaji, tunjangan, dan bentuk kemaslahatan lainnya. Hal ini secara panjang lebar dimuat dalam 11 item sebagai bentuk penghargaan pemerintah dan masyarakat terhadap guru (pasal 14-19). Di samping itu guru juga diberi jaminan perlindungan ketika menjalankan tugasnya, serta kesempatan membina dan mengembangkan kompetensinya dengan anggaran dari pemerintah.

Dalam perspektif kebijakan Nasional, Pemerintah telah merumuskan empat Jenis Kompetensi guru, sebagaimana tercantum dalam Pendidikan Peraturan Pemerintah No. 19 Tahun 2005 Tentang Standar Nasional Pendidikan, Yaitu: Kompetensi Pedagogis, Kepribadian, social, dan Profesional. Guru diharapkan dapat menjalankan tugasnya secara Profesional dengan memiliki dan menguasai keempat kompetensi tersebut. Berikut penjelasannya;

1) Kompetenssi Pedagogis

Menurut Badan Standar Nasional Pendidikan. yang dimaksud dengan kompetensi Pedagogik adalah:

Kemampuan dalam pengelolaan peserta didik yang melituputi; (a) pemahaamn wawasan atau landasan kependidikan; (b) pemahaman tentang peserta didik, (c) pengembangan kurikulum/silabus, (d) perancangan pembelajaran; (e) pelaksanaan pembelajaran yang mendidik dan dialogis; (f) evaluasi hasil belajar; dan (g) pengembangan peserta didik untuk mengatualisasikan berbagai potensi yang dimiliki.

Menuru Horowitz, el al. menjelaskan tentang kriteria guru yang baik dan efektif berikut ini: guru yang baik memahami bahwa mengajar bukan sekedar berbicara, dan belajar bukan sekedar mendengarkan. Guru yang efektif mampu menunjukan bukan hanya apa ingin mereka ajarkan, namun juga bagaimana siswa dapat memahami dan menggunakan pengetahuan dan keterampilan baru. Selanjutnya, mereka tahu apa yang mereka butuhkan siswa, 
maka mereka memilih tugas yang produktif, dan mereka menyususn tugas ini melalui cara yang menimbulkan pemahaman. Akhirnya, mereka memantau keterlibatan siswa di sekolah, belajar produktif, dan tumbuh sebagai anggota masyarakt yang kooperatif dan bijak sana yang akan dapat berpartisipasi.

2) Kompetensi Kepribadian

Kompetensi kepribadinan, yaitu “ kemampuan kepribadian yang: (a) berakhlak mulia; (b) mantap, stabil, dan dewasa; (c) arif dan bijaksana; (d) menjadi teladan; (e) mengevaluasi kinerja sendiri; (f) mengembangkan diri; dan (g) religious".

Menurut Huasin dan Asraf "Dalam dunia Kontemporer saat ini perhatian lebih ditunjukan pada bagunan, peralatan, perlengkapan, dan materi, dibandingkan pada kepribadian dan karakter guru." Kritik ini layak direnungkan oleh manajemen lembaga pendidikan dan fakultas pencetak calon guru.

Mulyasana dan Phenix menulis,"Esensi makna etika, atau pengetahuan moral, adalah perbuatan yang benar, yaitu, apa yang seharusnya seseorang lakukan.
3) Kompetensi Sosial

Kompetensi social merupakan kemampuan pendidik sebagai bagian dari masyarakt untuk: (a) berkomunikasi lisan dan tulisan; (b) menggunakan teknologi komunikasi dan informasi secara fungsional; (c) bergaul secara efektif dengan peserta didik, sesama pendidik, tenaga pendidik, orang tua/wali peserta pendidik; dan (d) bergaul secara santun dengan masyarakat sekitar.

Menurut Sukmadinata, "Di antara kemampuan social dan personal yang paling mendasar yang harus dikuasai guru adalah idealism, yaitu cita-cita luhur yang ingin dicapai dengan pendidikan." Cita-cita semacam ini dapat diwujudkan guru melalui, pertama, kesungguhan mengajar dan mendidik para murid. Tidak peduli kondisi ekonomi, social, poitik, dan medan yang dihadapinya. la selalu semangant memberikan pengajran kepada muridnya.

4) Kompetensi Profesional

Kompetensi Profesional adalah kemampuan penguasaan materi pembelajaran secara luas dan mendalam yang meliputi; (a) konsep, struktur, dan metode keilmuan/teknologi/seni yang menaungi/koheren dengan materi ajar; 
(b) materi ajar yang ada dalam Sisdiknas No. 14 Tahun 2005 bahwa kurikulum sekolah; (c) kompetensi guru adalah pendidik professional secara professional dalam konteks global dengan tugas utama mendidik, dengan tetap melestaraikan nilai dan mengajar, membimbing, mengarahkan, budaya nasional.

Dalam prosen penyelenggaraan pendidikan. Gedung sekolah, dana, program, dan kepemimpinan adalah vital. Demikian juga sumber manusia, dari kepala sekolah, guru, dan staf memmegang peranan yang sangat penting. Sumidjo menyatakan, "Faktor yang paling esensial dalam proses pendidikan adalah manusia yang ditugasi dengan pekerjaan untuk melatih, dan mengevaluasi peserta didik, dan guru wajib memiliki kualifikasi akademik, kompetensi, sertifikat Pendidik, sehat jasmani dan rohani dan Serta memiliki kemampuan untuk mewujudkan tujuan pendidikan nasional. Ahmad Tafsir menyebutakn bahwa guru harus dewasa dan ahli maknanya sama dengan pengertian guru yang professional dalam UndangUndang Sisdiknas.

menghasilkan perubahan yang telah direncanakan pada anak didik. Hal ini merupakan esensi dan hanya dapat dilakukan sekelompok manusia professional, yaitu manusia yang memiliki kompetensi mengajar".

\section{Penutup}

Dalam pandangan Ahmad Tafsir bahwa guru adalah pendidik yang tugasnya mendidik yang harus menjadi teladan bagi muridnya, dewasa, ahli, berkesusilaan, berkepribadian Muslim, dan, berdedikasi tinggi.

Pandangan Ahmad Tafsir tentang Guru dalam Pendidikan Islami tersebut relevan dengan Undang-Undang 


\section{DAFTAR PUSTAKA}

Djamarah, Bahri Syaiful, 2005, Guru dan anak Didik dalam Interaksi Edukatif, Jakarta: PT Rineka Cipta.

Horowitz, Dariling-Hmmod, Bransford, et al, 2005, Education Teacher for development appropriate practice.

Husain, Adian, 2013, Filsafat Ilmu Prespektif Barat dan Islam, Jakarta, Gema Insani

Mahfudz, Asep, 2011, 6 Rahasia Menjadi Pendidik 100\% Super Profesionla, Duta Kharisma Publishing.

Muhaimin, 2011, Pemikiran dan Aktualisasi Pengembangan Pendidikan Islam, Jakarta, Rajawali Press.

Muchtar, Juhairi, Heri, 2005, Fikih Pendidikan, Bandu: Remaja Rosdakarya.

Nata, Abuddin, 2009, Perspektif Islam tentan Strategi Pembelajaran, Jakarta, Kencana. 2006, Perspektif Hadist Tengtang Pendidikan, Jakarta: UIN Syarif Hidayatullah.

Nurdin, Muhamad, 2004, Kiat Menjadi Guru Profesional, Jogjakarta, Prismasophie.

Ramayulis, 2010, Metodologi Ilmu Pendidikan Agama Islam, Jakarta, Kalam Mulia. , 2007, Psikologi Agama, Jakarta: Kalam Mulia.

Rosyidin, Dedenga, 2009, Konsep Pendidikan Formal Islam, Bandung: Pustaka Nadwa.

Sastra, Ahmad, 2004, Filosofi Pendidikan Islam, Bogor, Darul Muttaqin Press.

Soetjipto dan Kosasi, Raflis, 2009, Profesi Keguruan, Jakarta: Rineka Cipta.

Sukamdinata, Syaodih, Nana, 2003, Landasan Psikologi Proses Pendidikan, Bandung: Remaja Rosdakarya.

Tafsir, Ahmad, 2000, Kuliah-Kuliah Tasawuf, Bandung: Pustaka Hidayah,

-.----, 2004, Filsafat IImu Mengurai Ontologi, Epistemologi dan Aksiologi

Pengetahuan, Bandung: Remaja Rosdakarya.

-.----, 2006, Filsafat Pendidikan Islami, Bandung: Remaja Rosdakarya

------, 2004, Filsafat Umum Akal dan Hati Sejak Thales Sampai Capra, Bandung: PT

Remaja Rosdakarya,

-a-a-, 2004, IImu Pendidikan dalam Perspektif Islam, Bandung: Remaja

Rosdakarya, 
Pemikiran Ahmad Tafsir tentang Guru:...(Jajang Badruzaman)

-.----, 2002, Metodologi Pengajaran Agama Islam, Bandung: Remaja Rosdakarya.

Peraturan Menteri Pendidikan Nasional Republik Indonesia No. 23 Tahun 2006 Tentang Standar Kompetensi Lulusan untuk Satuan Pendidikan Dasar dan Menengah.

Tim Prima Pena, 2006, Kamus Ilmiah Populer, Surabaya, Gitamedia Press.

Undang-Undang Republik Indonesia Nomor 14 Tahun 2005 tentang Guru dan Dosen.

Undang-Undang Republik Indonesia Nomor 20 Tahun 2003 tentang Sistem Pendidikan Nasional.

Usman, Moh. Uzer. 1997, Menjadi Guru Profesional. Bandung: PT Remaja Rosdakarya.

Yamin, Martinis, 2007, Profesionalisasi Guru dan Implementasi KTSP, Jakarta, Gaung Persada Press.

Yusanto, Ismail, et al.,2011, Menggagas Pendidikan Islam, Bogro: Al-Azhar Press. 